\title{
Vulnerability to pine sawfly damage decreases with site fertility but the opposite is true with Scleroderris canker damage; results from Finnish ICP Forests and NFI data
}

\author{
Seppo Nevalainen • Seija Sirkiä • Mikko Peltoniemi • \\ Seppo Neuvonen
}

Received: 31 May 2014 / Accepted: 29 October 2014 /Published online: 19 November 2014

(C) INRA and Springer-Verlag France 2014

\begin{abstract}
- Key message The probability of pine sawfly damage was highest in drier sites, while Gremmeniella abietina damage showed an opposite pattern. ICP Forests and rolling National Forest Inventory (NFI) data have good potential for quantifying patterns in damage occurrence, but region-wise NFIs may produce biased results.
\end{abstract}

\footnotetext{
Handling Editor: Marco Ferretti

Contribution of the co-authors Seppo Nevalainen: planning of the study, arrangement of field data, analysis of disease data, and writing the paper. Seija Sirkiä: statistical analyses, writing the paper. Mikko Peltoniemi: planning and partial funding and of the study, participated in arrangement of data, selection of methods, and writing the paper. Seppo Neuvonen: planning of the study, analysis of pine sawfly data, statistical analyses, and writing the paper.
}

Executive summary The probability of pine sawfly damage was highest in drier sites while Gremmeniella abietina damage showed an opposite pattern. ICP Forests and rolling National Forest Inventory (NFI) data have good potential for quantifying patterns in damage occurrence, but regionwise NFIs may produce biased results.

Electronic supplementary material The online version of this article (doi:10.1007/s13595-014-0435-8) contains supplementary material, which is available to authorized users.

S. Nevalainen $(\bowtie) \cdot S$. Sirkiä $\cdot S$. Neuvonen

Finnish Forest Research Institute, P.O., Box 68, 80101 Joensuu,

Finland

e-mail: seppo.nevalainen@metla.fi

S. Sirkiä

e-mail: seija.sirkia@metla.fi

S. Neuvonen

e-mail: seppo.neuvonen@metla.fi

\section{Peltoniemi}

Finnish Forest Research Institute, Vantaa, Finland

e-mail: mikko.peltoniemi@metla.fi
- Context Factors affecting the occurrence of important biotic damage on Pinus sylvestris were studied with data from largescale forest monitoring networks.

- Aims We tested how much the probability of damage caused by pine sawflies (Neodiprion sertifer Geoffr. and Diprion pini L.) and G. abietina (Lagerb. (Morelet)) differed between different forest site types and the effects of relevant climatic factors on damage probabilities.

- Methods Long-term damage observations from ICP Forests Level 1 monitoring and National Forest Inventory (NFI) data were used. In addition to the traditional frequentist approach, we used a hierarchical Bayesian (HB) framework with the ICP Forests data to model the probabilities of pine sawfly outbreaks starting and continuing.

- Results The probability of pine sawfly damage was highest in drier sites while the probabilities for G. abietina damage showed an opposite pattern. The HB analysis revealed clear differences between forest site types in the probability of outbreak starting, but the differences in the probabilities of outbreaks continuing were not clear.

- Conclusion ICP Forests and rolling NFI data have good potential for quantifying patterns in damage occurrence, but annually region-wise NFIs may produce biased results.

Keywords Forest damage · Pine sawflies ·

Neodiprion sertifer · Diprion pini .

Gremmeniella abietina $\cdot$ Pinus sylvestris

\section{Introduction}

Extensive forest health monitoring on ICP Forests Level 1 plots have been carried out in Finland since 1986, under the International Co-operative Programme on Assessment and Monitoring of Air Pollution Effects on Forests (ICP Forests). The basic aim in forest health monitoring is to gain knowledge 
of forest condition and its relationships to different stress factors (Lorenz 1995). Damage recording within forest health monitoring can reveal useful information about the temporal and spatial variations of the most important pests and pathogens (e.g. Nevalainen et al. 2010; Wulff et al. 2006).

The main aim of the National Forest Inventories (NFIs) in Finland is to estimate the volume and growth of the growing stock and cutting potential. Other aims, like forest health, multiple use of forests and biodiversity have become more and more important in the recent inventories. Detailed observations of damaging agents were first included in NFI 8 (1986-1994).

Pine sawflies (Neodiprion sertifer Geoffr. and Diprion pini L.) are a common problem in boreal pine forests of Northern Europe (Hanski 1987; Juutinen 1967; Kangas 1963; Larsson and Tenow 1984). The outbreaks of pine sawflies typically occur at irregular intervals (Juutinen 1967; Soubeyrand et al. 2010), and they tend to be preceded by drought periods (Larsson and Tenow 1983, 1984). Pine sawfly outbreaks are also generally considered to be more common in drier rather than in more fertile forests (Juutinen 1967; Larsson and Tenow 1984; Kouki et al. 1998; Meshkova 2006; Virtanen et al. 1996). However, the differences in outbreak probabilities between different site types have not been quantified on the basis of empirical data. On the other hand, the outbreaks of $N$. sertifer are rare in regions with cold winters because this species overwinters as eggs, which are killed at temperatures colder than $-35^{\circ} \mathrm{C}$ (Austarå 1971; Virtanen et al. 1996).

Gremmeniella abietina (Lagerb.) Morelet var. abietina is the causative agent of Scleroderris canker on coniferous trees. In Southern Finland, it is the most common fungal disease in forests dominated by Scots pine (Pinus sylvestris L.). The disease is epidemic in nature. If the host trees, Scots pines in this case, are of local origin, meteorological factors and site conditions determine the degree of predisposition. The disease has been found to be more frequent on rich sites, at least in mineral soils and in drained peatlands (compared to undrained peatlands and mineral soils) (Nevalainen 1999; Nevalainen and Mattila 2002).

Annual variations in weather conditions have an effect on the build-up of the disease. Epidemics are common after cold and rainy growing seasons (Aalto-Kallonen and Kurkela 1985; Uotila 1988).

Our aim was to test hypotheses on the occurrence of pine sawfly and G. abietina damage in pine forests in Finland and to quantify the effects of some environmental factors. These damage causes are economically important, common in the monitoring data in Finland and are related to the opposite ends of the moisture continuum. We used different types of forest damage monitoring data to evaluate their suitability for damage modeling: ICP Forests Level 1 data and two different kinds of NFI data (annually region-wise $=$ NFI 8 and NFI 9; rolling NFI=NFI 10; see Table 1):

Specifically, we examined the following questions:

- How much does the probability of pine sawfly damage vary between different forest site types?

- Is the frequency of pine sawfly damage in different parts of Finland related to the likelihood of cold winters?

- How much does the probability of Scleroderris canker (G. abietina) damage vary between different forest site types?

- Is the frequency of Scleroderris canker related to the amount of rainfall during the growing season?

\section{Material and methods}

\subsection{Field plots}

Permanent sample plots of ICP Forests Level I were established during 1985-1986 in connection with NFI 8. A systematic subsample of 450 permanent, mainly mineral soil plots was initially selected for extensive forest health monitoring (Nevalainen et al. 2010). The country was divided into a southern and a northern region (demarcation line $66^{\circ} \mathrm{N}$ ). The network in the southern region was based on a $16 \times 16-\mathrm{km}$ grid, and in the northern region on a $24 \times 32-\mathrm{km}$ grid. The size of the circular sample plot was originally $300 \mathrm{~m}^{2}$.

All the dominant and co-dominant Scots pine, Norway spruce (Picea abies L. [Karst]) and birch (Betula pendula

Table. 1 Types of data and number of plots used in this study.

\begin{tabular}{llllll}
\hline Data & Observation level & Regional coverage & Number of plots/year (min-max) & Total number of plots & Years \\
\hline ICP Forest Level 1 & Tree level & Whole Finland & $242-455$ & $7416^{\mathrm{a}}$ & $1986-2008$ \\
Finnish NFI8 & Plot level & Annually changing regions & $665-7309$ & 36,082 & $1986-1994$ \\
Finnish NFI9 & Plot level & Annually changing regions & $2971-5227$ & 34,550 & $1996-2003$ \\
Finnish NFI10 & Plot level & Whole Finland & $3217-6019$ & 28,503 & $2004-2008$ \\
\hline
\end{tabular}

Please note that only Scots pine trees and/or Scots pine-dominated plot center points were used in this study. For ICP Forests Level 1 data, the total number of plot years is the number of times the plots were visited during the years

NFI National Forest Inventory

${ }^{\text {a }}$ Plot years 
Roth and Betula pubescens Ehrh.) trees on the plot were assessed for damage. In this study, we used only damage observations from Scots pine trees. The total number of assessed plots and observation trees varied between the years, due to cuttings and the selection of new trees within each plot (by increasing the size of the plot), as well as to the addition of completely new plots since 1995 (Table 1). Site type data from the main forest compartment was used.

Detailed plot and sample tree level observations of damaging agents were first included in NFI 8 (Eight Finnish National Forest Inventory) in 1986-1994. In NFI 9 (1996-2003), these aspects were further developed. In NFI 10 (2004-2008), the inventory cycle was decreased to 5 years from the $8-10$ years of the previous NFIs, and a portion of the field plots were measured throughout the country every year (=rolling NFI), while in NFI 8 and NFI 9, one region of the country was inventoried each year.

The field plots of NFIs have been arranged in detach L- or square-shaped tracts. Relascope (Bitterlich) plots have been used instead of fixed-size plots. Survey designs have been somewhat variable in different inventories and in different parts of the country. The distance between tracts increases from south to north, and was $6 \times 6 \mathrm{~km}$ in Southern and $10 \times$ $10 \mathrm{~km}$ in Northernmost Finland, e.g. in NFI 10. Each tract comprised 14-18 relascope plots, with a $250-$ or $300-\mathrm{m}$ distance between plots. In this study, we used only plot-wise damage data, and only Scots pine-dominated plots.

Both in the case of ICP Forests and NFI plots, a plot can include many stands. A 'stand' is defined here as a growing stock that is homogeneous with respect to administrative boundaries, land use, principal site class, site fertility and the structure of the growing stock (development class and tree species composition), accomplished or needed silvicultural and cutting operations (Tomppo et al. 2011). In this study, data was only used for the forest stand where the plot center was located.

For the number of plots used in this study, see Table 1.

\subsection{Assessment of damage}

In the ICP Forests Level 1 plot, the variables related to tree health were assessed visually according to internationally standardized methods (Eichhorn et al. 2010) and national field guidelines (Lindgren et al. 2005, unpublished). A national system for the description of the damage: symptom, apparent severity (degree of damage) and the cause, as well as the age of the damage, was used prior to 2004. The ICP Forests manual of damage causes (referred to as the biotic manual) was fully adopted in 2005 in Finland. The principles of the national damage survey in Finland before 2004 were to a large extent similar to the current biotic manual, but the damage cause classification was more detailed after 2005 (see Nevalainen et al. 2007). The survey was carried out annually, during July and August, by 10 to 12 trained observers. Every year, a theoretical and practical training course was held before the survey period, and the consistency between observers has been checked. To check for plausibility, national calibration courses were arranged at regular intervals.

Since NFI 8, forest damage has been assessed in every NFI plot situated on forest land (according to the Finnish definition, the mean annual increment of wood should be at least $1 \mathrm{~m}^{3} \mathrm{ha}^{-1}$ on forest land). The possible occurrence of damage is assessed at the sample tree and at the stand levels. The damage was assessed using three different codes: the symptom, the cause and the possible effect of damage for the silvicultural quality of the stand (damage degree). In the case of multiple damage, their summed importance for the stand quality was recorded. Each year, the field work was normally carried out by $8-14$ teams, each usually consisting of a team leader and two assistants. Detailed information of the Finnish NFIs (NFI 9) can be found in Tomppo et al. (2011) and at http://www.metla.fi/ohjelma/vmi/info-en.htm.

In the analysis, we used ICP Forests Level 1 damage data from Scots pine trees from 1986-2008. With NFIs, we used stand level damage assessments from Scots pine-dominated plots and combined the region-wise NFIs (NFI 8 and NFI 9) into one dataset, and analysed NFI 10 (rolling NFI) data separately.

\subsection{Explanatory variables}

The most important variable used in this study was the site classification done during the fieldwork. The original classification in the NFIs is based on the composition of ground vegetation (for definition of the used classes, see Tomppo et al. 2011). In the analysis, we used five classes for the following sites:

A Mineral soils: herb-rich heath forests and more fertile types (groves) (Myrtillus-type) and more fertile sites, according to the Finnish site classification

B Mineral soils: mesic heath forests

C Mineral soils: sub-xeric heath forests and poorer types (Vaccinium-type) and poorer types according to the Finnish site type classification

D Spruce mires

E Pine mires

Climatic data was obtained from standard daily weather data interpolated to a $10-\mathrm{km}$ regular grid by the Finnish Meteorological Institute. The interpolation method works well with daily temperatures, but the long-term annual average precipitation is somewhat underestimated (Venäläinen et al. 2005). We calculated two aggregate variables per grid point to be used in our analysis, summer rainfall and likelihood of cold winters. The first was calculated as an average over the available data period (1960-2012) of the rainfall observations from May to September each year. The latter was calculated as

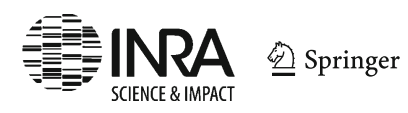


a straightforward proportion of years with minimum winter temperature below $-35^{\circ} \mathrm{C}$. The values of these variables from the nearest weather grid point were used for each ICP Forests Level 1 and NFI plot in the analyses.

\subsection{Data analysis}

The tree-wise damage observations in the Level 1 ICP Forests plots were aggregated for each plot in the statistical analysis. The plot was marked as "diseased" in a given year, if at least $33 \%$ of the trees had visible injury attributed to pine sawflies or were recorded to have symptoms caused by G. abietina. We chose a moderate incidence ( $33 \%$ ) as the cut point here, as lower incidences normally have no or very low economic importance. Furthermore, in preliminary analyses, we found that cut points in the range of about 15 to $40 \%$ yielded similar results so that the exact choice does not affect the conclusions.

The number of diseased years among observation years per plot was used as the binomial response variable in a generalized linear model with a logit link. The same model was then applicable also to the NFI data where damage observations are collected on the plot level. In this case, there is always a single observation year per plot.

The model form is

$$
\begin{aligned}
\operatorname{logit}(\text { risk of diseased year })= & \alpha+\beta_{\mathrm{A}} * d_{\mathrm{A}}+\beta_{\mathrm{C}} \\
& * d_{\mathrm{C}}+\beta_{\mathrm{D}} * d_{\mathrm{D}}+\beta_{\mathrm{E}} \\
& * d_{\mathrm{E}}+\gamma * x
\end{aligned}
$$

where variables $d_{\mathrm{A}}$ to $d_{\mathrm{E}}$ are dummy variables for the site types and $x$ is a continuous covariate. The site type $\mathrm{B}$, being the most common, was chosen as the reference level. This means that the intercept term $\alpha$ includes the effect of $\mathrm{B}$, and that the site type parameters $\beta_{\mathrm{A}}$ to $\beta_{\mathrm{E}}$ stand for the difference between that site type and $\mathrm{B}$. Consequently, the $p$ values for these parameters shown in the result tables are for a null hypothesis of there being no difference between site type B and that site type. For the continuous covariate, the $p$ value shown is for the usual significance test of the term.

We also used a hierarchical Bayesian (HB) framework in modeling the damage outbreaks based on the 23 years of ICP Forests Level 1 data (1986-2008). For this purpose, the data were seen as yearly plot-wise recordings of two numbers, the total number of observed trees and the number of damaged trees. In the case of pine sawflies, for example, the proportion of damaged trees is driven by the abundance of larvae in the area at the given time. The abundance in turn is driven by the population dynamics of pine sawflies, which is affected by a multitude of factors (e.g. winter temperatures, predation, virus epidemics, parasitoids and food quality; Hanski, 1987;
Larsson and Tenow, 1984; Neuvonen et al. 1990; Saikkonen et al., 1995; Virtanen et al. 1996).

We modeled a simplified version of this process. The number of damaged trees is assumed to have a binomial distribution with the probability parameter dependent through a logit link on the population process, which in turn is assumed to have only two possible states, endemic and outbreak. This leads to the modeling of interesting transition probabilities of an outbreak starting and an outbreak continuing. For these, we chose the same form of linear predictor and logit link as with the generalized linear models used in the other analyses meaning that in this sense the different approaches are in accordance. However, this model is better able to take the population dynamic in to account, by modeling the probabilities of outbreaks starting and ending instead of a constant annual risk. This approach was only possible in the multiannual ICP Forests Level 1 data for the pine sawfly damage. Full description of the model is given in the electronic supplementary material (Table S1).

In the HB analysis, tests of significance of terms are replaced by examining the posterior distributions of the relevant parameters. The difference in risk of damage between site types can be assessed by calculating posterior probabilities of claims of the form "the parameter for A is smaller than the parameter for B". Very high (or very low, depending on the direction of the difference) probabilities imply a difference between the site types.

Analyses were done using the $\mathrm{R}$ environment ( $\mathrm{R}$ core team, 2013). For the hierarchical Bayesian model, package rjags (Plummer 2014) was used.

\section{Results}

\subsection{Pine sawfly damage}

The incidence of damage in all data sets was significantly related to both forest site type and the likelihood of winter cold, as shown by results from fitting the same generalized linear model for the pine sawfly damage on the three data sets. However, the sign of the winter cold effect was negative in ICP Forests and NFI10 data but positive in NFI 8 and NFI 9 data (Table 2).

On mineral soils, the probability of damage increased with decreasing site fertility, being clearly, 1.5- to 4-fold, higher in semi-xeric and poorer heath forests than in mesic heath forests (Fig. 1). In herb-rich heath forests and more fertile types, the probability of pine sawfly damage was in all data sets less than one third of that in mesic heath forests (Fig. 1). On peatlands, the probability of damage was highest in pine mires, where it was 1.5 - to 3.5 -fold compared to the probability in the site 
Table. 2 The effects of site type (A-E; see text and legend of Fig. 1) and the likelihood of cold winter on the probability of pine sawfly damage. Parameter estimates (and standard deviation), with the $p$ values of the tests of significance of the term, of the linear predictor of the GLM (see Eq. 1 in the "Data analysis" section) fitted on different data sets

\begin{tabular}{lccc}
\hline & ICP Forests Level 1 & NFI 8 and NFI 9 & NFI 10 \\
\hline Intercept $(\alpha$, effect of B) & $-3.34(0.16)$ & $-6.88(0.16)$ & $-4.48(0.16)$ \\
Difference of A to B $\left(\beta_{\mathrm{A}}\right)$ & $-1.17(0.40)$ & $-13.2(185.7)$ & $-1.06(0.59)$ \\
& $p=0.003$ & $p=0.94$ & $p=0.076$ \\
Difference of C to B $\left(\beta_{\mathrm{C}}\right)$ & $0.43(0.17)$ & $1.28(0.14)$ & $0.89(0.17)$ \\
& $p=0.012$ & $p<0.001$ & $p<0.001$ \\
Difference of D to B $\left(\beta_{\mathrm{D}}\right)$ & $-1.37(1.01)$ & $-0.39(0.33)$ & $-0.64(0.59)$ \\
& $p=0.176$ & $p=0.234$ & $p=0.279$ \\
Difference of E to B $\left(\beta_{\mathrm{E}}\right)$ & $0.91(0.29)$ & $1.19(0.15)$ & $0.45(0.21)$ \\
& $p=0.002$ & $p<0.001$ & $p=0.030$ \\
Effect of the likelihood of cold winter & $-3.75(0.68)$ & $3.80(0.28)$ & $-5.31(0.68)$ \\
$(\gamma)$ & $p<0.001$ & $p<0.001$ & $p<0.001$ \\
\hline
\end{tabular}

type B (mesic heath forests on mineral soils) chosen as the reference level (Fig. 1).

In the hierarchical Bayesian (HB) analysis (ICP Forests Level 1 data), the probabilities of a starting pine sawfly outbreak differed very clearly between site type B and other site types in most cases (Fig. 2). This was shown by the posterior probabilities of the corresponding parameters being smaller than for B, which were either $>0.99$ or $<0.01$, except in the case of site type $\mathrm{D}$ for which it was 0.43 . Also, the posterior probability of the coefficient for the likelihood of cold winters differed distinctly from zero $($ mean $=-3.70$ with the $95 \%$ posterior interval -5.30 to -2.1 ), meaning that increased likelihood of cold winters notably decreases the probability of pine sawfly outbreaks starting. The estimated parameters for the probabilities of the outbreak continuing for another year after being in progress did not differ clearly between forest site types (see Table S2, Electronic supplementary material).

\subsection{G. abietina damage}

The results of fitting the similar generalized linear model to the occurrence of $G$. abietina damage showed somewhat different results in different datasets (Table 3, Fig. 3). On mineral soils in ICP Forest Level 1 and NFI 8 and NFI 9, the probability of the damage increased with increasing site fertility, being higher (1.6- to 1.7-fold) in richer herb-rich heath forests and more fertile types (groves), as compared to the reference site $\mathrm{B}$ (the mesic heath forests). In site type $\mathrm{C}$ (sub-xeric heath forests and poorer types in mineral soils), the damage probability was smaller than in the reference site type.

In the NFI 10 dataset, the general level of the disease was low in the mineral soil plots, and the difference between the richest sites and the reference site was not significant. The probability of the disease was highest in pine mires (site type E), except in the ICP Forests Level 1 dataset. The probability was 1.3-3.7 times higher than in the reference mineral site type, except in the ICP Forests Level 1 dataset. The rainfall
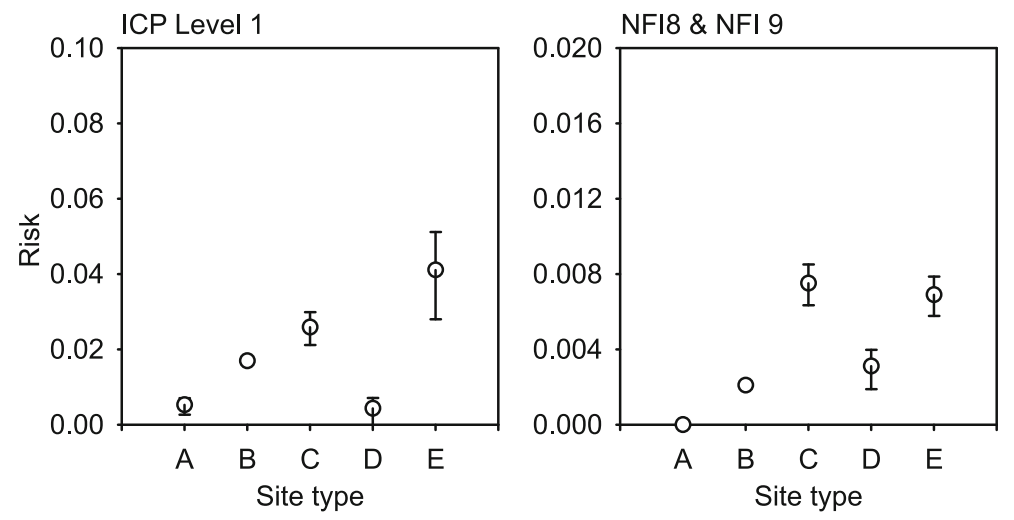

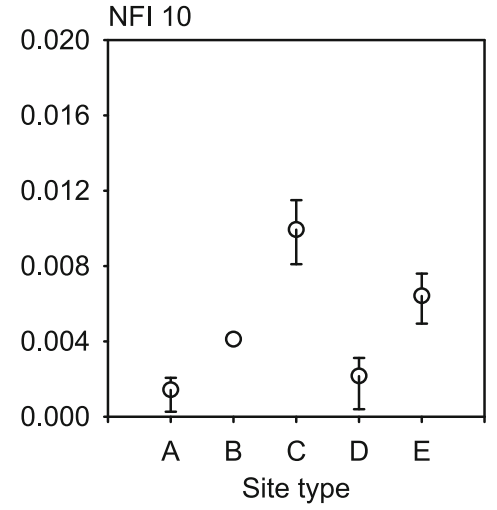

$C=$ sub-xeric heath forests and poorer types; $D=$ spruce mires; $E=$ pine mires. Uncertainty illustrated by the standard errors (asymmetric scale) is related to the difference between site types. Uncertainty that is common to all site types, that is, related to the intercept (=site type B) and covariate, is not shown here. In the NFI 8 and NFI 9 data, the data was insufficient to calculate the standard errors for site type A
Fig. 1 The fitted risks (the probability parameter of the binomial distribution) of pine sawfly damage (at least $33 \%$ of pines with pine sawflies) on different forest site types A-E, predicted by the GLM (calculated for the mean likelihood [0.19] of cold (minimum temperature $<-35{ }^{\circ} \mathrm{C}$ ) winters), and fitted in different data sets. Site types: $A-C-$ mineral soils: $A=$ herb rich heat forests and more fertile types; $B=$ mesic heath forest; 
ICP Level 1

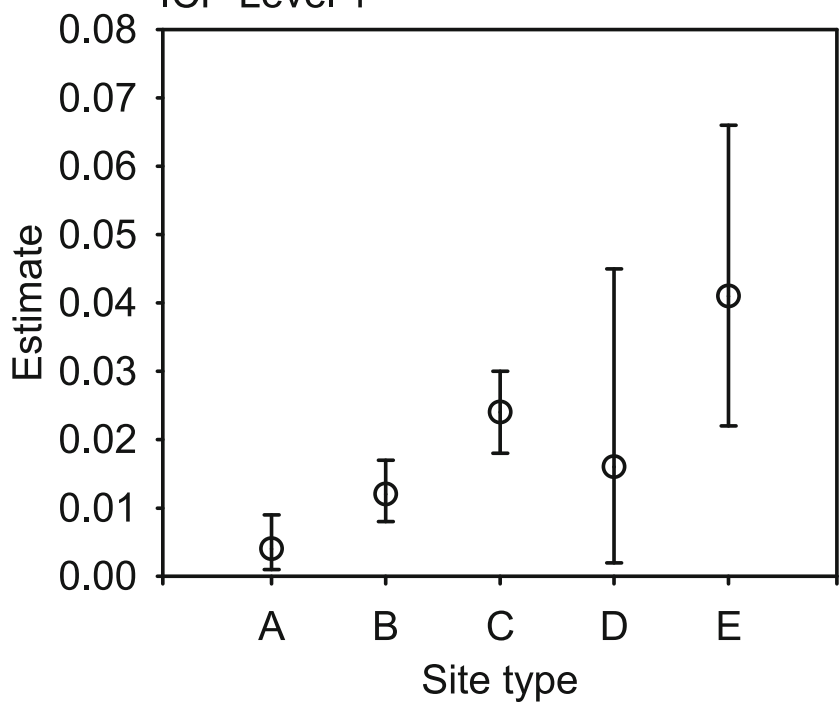

Fig. 2 Posterior estimates (hierarchical Bayesian analysis of ICP Forests Level 1 data) of the probabilities (dots indicate mean annual risk) of a pine sawfly outbreak starting (with $95 \%$ posterior intervals) in different forest site types (see text and legend of Fig. 1). Estimates are calculated for the mean value of the likelihood of cold winters $(0.19)$

also had a significant effect, except in the NFI 10 data (Table 3).

\section{Discussion}

The results of this study show that both ICP Forests Level 1 forest health monitoring data and forest damage observations collected during rolling NFIs are useful when quantifying the risks of damage by specific biotic agents in relation to environmental factors. Here, we have focused on the probability of damage in different forest site types by two different damage agents, facilitated by the opposite ends of the moisture continuum.

Qualitatively, it is well known that pine sawfly damages are more common in drier forests rather than in moister and more fertile forests (e.g. Hanski 1987; Juutinen 1967; Larsson and Tenow 1984). There are different opinions about the actual

Table 3 The effects of site types (A-E; see text and legend of Fig. 1) and rainfall during May-September on Gremmeniella abietina damage. Parameter estimates (and standard deviation), with the $p$ values of the tests mechanisms involved: some suggest that changes in host plant quality are important (Larsson and Tenow 1983, 1984; Saikkonen et al. 1995), while others stress the role of cocoon predation by small mammals (Hanski 1987; Hanski and Parviainen 1985; Kouki et al. 1998). In this study, we have used both long-term (ICP Forests) and "snapshot" (NFIs) observations to quantify pine sawfly damage occurrence in relation to forest site types. The differences between site types were consistent with earlier (qualitative) knowledge and among different data sets. In principle, this kind of quantitative information can be used when combined with information derived from multisource forest inventories (Tomppo et al. 2011), e.g. to produce damage risk maps for the whole country (work in progress).

Earlier studies have shown that European pine sawfly outbreaks are rare in Eastern and Northern Finland, i.e. in areas with cold winters (Virtanen et al. 1996; Soubeyrand et al. 2010). This pattern was supported by the significantly negative coefficients for the covariate describing the probability of cold winters in the analyses with ICP Forests Level 1 and NFI 10 data, but this coefficient was positive with NFI 8 and NFI 9 data. We offer two (mutually nonexclusive) explanations for this discrepancy. First, there was a major outbreak of $D$. pini in Central Finland during NFI 9 (Varama and Niemelä 2001); D. pini overwinters as cocoons in the soil, protected from winter cold by insulating snow (Hanski 1987). Second, NFI 8 and NFI 9 were regional inventories, and they may have missed even large regional outbreaks because the inventory teams were working outside the outbreak area during the relevant years. Consequently, the results from NFI 8 and NFI 9 are probably biased with respect to regional scale covariates.

This study showed that in most cases, the risk of G. abietina infection is greater on richer forest site types, which is in line with some earlier findings (Nevalainen 1999; Nevalainen and Mattila 2002). There are very few scientific reports on the effects of site fertility; however, in Finland, forests are usually more fertile on fine-textured soils. Pine stands have been reported to deteriorate when the proportion of fine soil of significance of the term, of the linear predictor of the GLM (see Eq. 1 in the "Data analysis" section) fitted on different data sets

\begin{tabular}{llll}
\hline & ICP Forests Level 1 & NFI 8 and NFI 9 & NFI 10 \\
\hline Intercept $(\alpha$, effect of B) & $-3.90(0.49)$ & $-6.61(0.23)$ & $-3.33(0.48)$ \\
Difference of A to B $\left(\beta_{\mathrm{A}}\right)$ & $0.64(0.09) p<0.001$ & $0.50(0.07) p<0.001$ & $-0.26(0.25) p=0.296$ \\
Difference of $\mathrm{C}$ to B $\left(\beta_{\mathrm{C}}\right)$ & $-0.36(0.08) p<0.001$ & $-0.43(0.05) p<0.001$ & $0.21(0.10) p<0.044$ \\
Difference of $\mathrm{D}$ to B $\left(\beta_{\mathrm{D}}\right)$ & $0.28(0.20) p=0.156$ & $0.75(0.06) p<0.001$ & $0.78(0.17) p<0.001$ \\
Difference of $\mathrm{E}$ to B $\left(\beta_{\mathrm{E}}\right)$ & $-1.33(0.28) p<0.001$ & $0.58(0.04) p<0.001$ & $1.33(0.09) p<0.001$ \\
Effect of rainfall $(\gamma)$ & $0.006(0.002) p<0.001$ & $0.01(<0.001) p<0.001$ & $-0.003(0.002) p=0.120$ \\
\hline
\end{tabular}




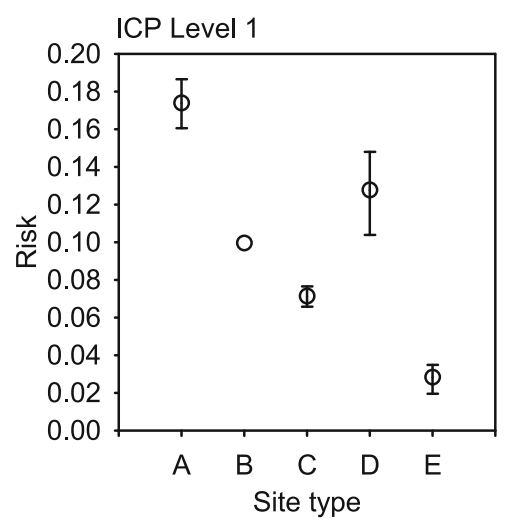

Fig. 3 The fitted risks (the probability parameter of the binomial distribution) of the occurrence of Gremmeniella abietina damage (33\% of pines showing damage symptoms) on different forest site types A-E (see Fig. 1), predicted by the GLM (calculated for the rainfall during MaySeptember $(272 \mathrm{~mm})$, and fitted in different data sets). Uncertainty

fractions increases (Lähde 1974). Some studies (e.g. Sairanen 1990) have found no differences in the damage occurrence between site types. The studies mentioned above have been local studies in heavily diseased areas and have been conducted on a limited number of sites, which may explain the discrepancy.

G. abietina damage is more common in Southern than in Northern Finland (Nevalainen 2007). However, the disease is not limited by cold winters, and it has caused damage in the north for a long time (Kaitera and Jalkanen 1993; Lähde 1974). Epidemics usually begin after cold and rainy growing seasons (Aalto-Kallonen and Kurkela 1985; Uotila 1988). The amount of rain during early summer may enhance the occurrence of the disease (Nevalainen and Mattila 2002). Although the effect of rain was small in this study, rainy weather during the summer definitely plays a role in increasing Gremmeniella epidemics. However, this requires that the inoculum potential is already high. The connection with weather factors may also be complex, e.g. in Northwestern Denmark low average temperatures and high precipitation in May combined with the same weather patterns in either August or September may be required for severe epidemics (Thomsen 2009). In Canada, low winter temperatures combined with high winter precipitation have been considered the decisive factor (Venier et al. 1998).

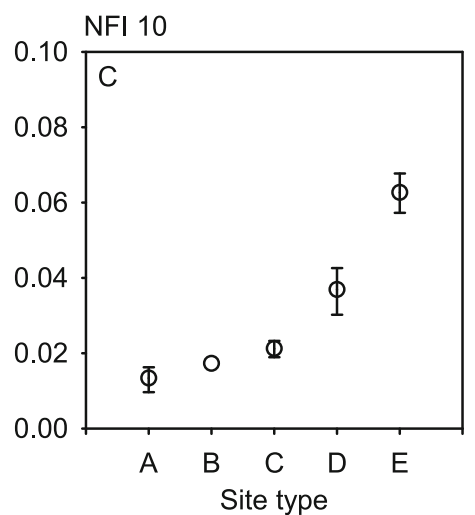

illustrated by the standard errors (asymmetric scale) is related to the difference between site types. Uncertainty that is common to all site types, that is, related to the intercept (=site type B) and covariate, is not shown here

The disease has been found to be almost twice as common on drained peatland sites than on mineral soil sites (Nevalainen 1999). Peatland sites were poorly represented in the ICP Forests data, and this explains the wide standard error (or posterior) intervals (Figs. 1, 2, 3) in site types D-E (spruce and pine mires) and the low fitted risk of G. abietina damage in these plots (Fig. 3). The occurrence of the disease in the NFIs has decreased (Nevalainen 2007), which may explain the different probabilities in NFI 10.

The long-term damage observations in the forest health monitoring data from ICP Forests Level 1 are essential and useful in increasing our understanding of the occurrence of important damage agents. Insect outbreaks or disease epidemics in Finland generally have so short a duration that snapshot observations (made during only 1 year) may miss even highly susceptible sites if the overall probability of damage agent occurrence during the observation year is low.

The main shortcoming of the ICP Forests level 1 data appears to be low sampling density.

The Level 1 network was originally planned to provide results valid at the European level. Earlier reports show that the most important and large-scaled damage epidemics are revealed at the country level in Finland (Nevalainen et al. 2010). However, the number of monitoring plots in the most

Table 4 The main advantages and disadvantages of different inventory types considered in the present study

\begin{tabular}{|c|c|c|}
\hline Monitoring/inventory type & Advantages & Disadvantages \\
\hline ICP Forests Level 1 in Finland & $\begin{array}{l}\text { Good temporal coverage; yields time series } \\
\text { at plot level, well trained observers, } \\
\text { detailed damage descriptions } \\
\text { (since 2005) }\end{array}$ & $\begin{array}{l}\text { Poor coverage in the north, rare forest types poorly } \\
\text { represented, only dominant and co-dominant } \\
\text { trees, peatland sites present only during the } \\
\text { last years of the study period }\end{array}$ \\
\hline Finnish NFI 8 and NFI 9 & Also rare forest types well represented & $\begin{array}{l}\text { Annually changing regional coverage may miss } \\
\text { even widespread outbreaks/epidemics }\end{array}$ \\
\hline Finnish NFI10 & $\begin{array}{l}\text { Also rare forest types well represented; } \\
\text { good spatial (country-wide) coverage }\end{array}$ & Not possible to get annual time series at plot level \\
\hline
\end{tabular}


barren site types and on peatlands was low in Finland; the situation may be different in other countries. For obtaining useful results with respect to pine sawflies, for example, the number of permanent monitoring plots in these barren site types should be increased. The inclusion of damage data from the NFIs greatly increased the number of observations on poorer site types, and supported and extended the conclusions based on Finnish ICP Forests Level 1 data.

National Forest Inventories are statistically representative samples of Finland's forests. The main problem with the earlier NFI damage observations was the shifting annual geographic coverage: NFI 8 and NFI 9 were regional inventories, i.e. only one region of the country was inventoried each year. During specific years, some regional insect and disease outbreaks may have remained underestimated on the basis of NFI data (see the distribution of pine sawfly damages during the peak year 2000 in Varama and Niemelä 2001); the actual outbreak area also included large areas South of the Oulu-Kajaani line, but these areas were not inventoried in NFI during 2000). The same problem was evident with G. abietina damage during the 1980s: The area where the epidemic broke out and became very common in 1988 was already inventoried during previous years.

Since NFI 10 (from 2004 onwards), the sampling design was changed in such a way that a portion of the field plots are measured throughout the country every year. This is a clear improvement to the earlier inventory design. Also, in NFI 10 , the inventory cycle was decreased to 5 years from the $8-10$ years of the previous NFIs. The advantages and disadvantages of various sources of damage data (ICP Forests vs. NFI 8 and NFI 9 vs. NFI 10) are summarized in Table 4.

The ICP Forests Level 1 plots were originally permanent sample plots of NFI 8, and more than 100 site variables were readily available; the same was true for the NFI plots. These variables describe the site, growing stock, damage and the need for silvicultural operations. Thus, there are plenty of recorded environmental variables, some of which may be used in further work examining other hypotheses about environmental variables behind the occurrence of specific biotic agents. Both ICP Forests type of data and observations from rolling NFIs (like NFI 10) seem to be suitable for these kinds of studies, but we stress that annually region-wise NFIs (like NFI 8 and NFI 9) may produce biased results with respect to regionally varying factors, and extra caution will be needed if this kind of data is used.

Funding The study was financed by the Finnish Forest Research Institute and by The EU Life+ project Climforisk (EU/ENV/FI/00571) during 2011-2014. The field work was supported by ICP Forests and European Commission in the Forest Focus project.

\section{References}

Aalto-Kallonen T, Kurkela T (1985) Gremmeniella disease and site factors affecting the condition and growth of Scots pine. Commun Inst For Fenn 126:1-28

Austarå Ö (1971) Cold-hardiness in eggs of Neodiprion sertifer (Geoffroy) (Hym., Diprionidae) under natural conditions. Norsk ent Tidsskr 18:45-48

Eichhorn J, P Roskams, M Ferretti, V Mues, A Szepesi, D Durrant (2010) Visual assessment of crown condition and damaging agents. $49 \mathrm{pp}$. Manual part IV. In: Manual on methods and criteria for harmonized sampling, assessment, monitoring and analysis of the effects of air pollution on forests UNECE ICP Forests Programme Co-ordinating Centre, Hamburg ISBN: 978-3-926301-03-1 [http://www.icpforests.org/Manual.htm]

Hanski I (1987) Pine sawfly population dynamics: patterns, processes, problems. Oikos 50:327-335

Hanski I, Parviainen P (1985) Cocoon predation by small mammals and pine sawfly population dynamics. Oikos 45:125-136

Juutinen P (1967) Zur Bionomie und zum Vorkommen der Roten Kieferbuschhornblattwespe (Neodiprion sertifer Geoffr.) in Finnland in den Jahren 1959-1965. Comm Inst For Fenn 63:1-129

Kaitera J, R Jalkanen (1993) History of the decline in the Rikkilehto Scots pine stand. In: Jalkanen R, Aalto T, Lahti M-L (eds) Forest pathological research in northern forests with a special reference to abiotic stress factors: extended SNS meeting in forest pathology in Lapland, Finland, 3-7 August, 1992, pp. 128-137

Kangas E (1963) Über das schädliche Auftreten der Diprion-Arten (Hym. Diprionidae) in finnischen Kiefernbeständen in diesem Jahrhundert. $\mathrm{Z}$ ang Ent 51:188-194

Kouki J, Lyytikäinen-Saarenmaa P, Henttonen H, Niemelä P (1998) Cocoon predation on diprionid sawflies: the effect of forest fertility. Oecologia 116:482-488

Larsson S, O Tenow (1983) Relations between drought stress in pine and outbreaks of needle-eating insects. A survey of hypotheses. In: Isaev, AS (ed.) The role of insect-plant relationship in the population dynamics of forest pests. Krasnoyarsk, pp 101-110

Larsson S, Tenow O (1984) Areal distribution of a Neodiprion sertifer (Hym., Diprionidae) outbreak on Scots pine as related to stand condition. Hol Ecol 7:81-90

Lorenz M (1995) International Co-operative Programme on Assessment and Monitoring of Air Pollution Effects on Forests-ICP Forests. Water, Air, and Soil Pollution 85:1221-1226

Lähde E (1974) The effects of grain size distribution on the condition of natural and artificial sapling stands of Scots pine. Commun Inst For Fenn 84:1-23

Meshkova V (2006) Foliage browsing insects risk assessment using forest inventory information. IUFRO Working Party 7.03.10 Proceedings of the Workshop 2006, Gmunden/Austria: 100-108

Neuvonen S, Saikkonen K, Haukioja E (1990) Simulated acid rain reduces the susceptibility of the European pine sawfly (Neodiprion sertifer) to its nuclear polyhedrosis virus. Oecologia 83:209-212

Nevalainen S (1999) Gremmeniella abietina in Finnish Pinus sylvestris stands in 1986-1992: a study based on the National Forest Inventory. Scand J For Res 14:111-120

Nevalainen S (2007) Spatial and temporal variation in the occurrence of Gremmeniella abietina in Scots pine in Finland. Acta silv lignaria Hung Spec Edition 2007:127-136

Nevalainen S, Lindgren M, Pouttu A (2007) Spatial and temporal patterns in the occurrence of biotic and abiotic damage in Finland. In: Eichhorn J (ed) Forests in a changing environment. Results of 20 years ICP Forests Monitoring, vol 142, Symposium. Schr Forstl Fak Univ Gött Niedersächs forstl Vers anst., pp 193-200

Nevalainen S, Lindgren M, Pouttu A, Heinonen J, Hongisto M, Neuvonen S (2010) Extensive tree health monitoring networks are 
useful in revealing the impacts of widespread biotic damage in boreal forests. Environ Monit Assess 168:159-171

Nevalainen S, Mattila U (2002) Factors affecting the risk of Gremmeniella abietina infection in Scots pine stands. Finn For Res Inst Res Pap 829:39-49

Plummer M (2014). rjags: Bayesian graphical models using MCMC. R package version 3-13. http://CRAN.R-project.org/package=rjags

R Core Team (2013). R: A language and environment for statistical computing. R Foundation for Statistical Computing, Vienna, Austria. URL http://www.R-project.org/

Saikkonen K, Neuvonen S, Kainulainen P (1995) Oviposition and larval performance of European pine sawfly in relation to irrigation, simulated acid rain and resin acid concentration in Scots pine. Oikos 74: 273-282

Sairanen A (1990) Site characteristics of Scots pine stands infected by Gremmeniella abietina in Central Finland. I. Mineral soil sites. Acta For Fenn 216: pp 27

Soubeyrand S, Neuvonen S, Penttinen A (2010) Mechanical-statistical modeling in ecology: from outbreak detections to pest dynamics. Bull Math Biol 71:318-338

Thomsen IM (2009) Precipitation and temperature as factors in Gremmeniella abietina epidemics. Eur J For Pathol 39:56-72
Tomppo E, J Heikkinen, HM Henttonen, A Ihalainen, M Katila, H Mäkelä, T Tuomainen, N Vainikainen (2011) Designing and conducting a forest inventory - case: 9th National Forest Inventory of Finland. Managing Forest Ecosystems 22: XII, 272 pp

Uotila A (1988) Ilmastotekijöiden vaikutus männynversosyöpätuhoihin. Summary: the effect of climatic factors on the occurrence of Scleroderris canker. Folia For 721:1-23

Varama M, Niemelä P (2001) Männiköiden neulastuholaiset (The defoliators in Scots pine forests) (in Finnish). Metsät aikak 2:275-279

Venäläinen A, Tuomenvirta H, Pirinen P, Drebs A (2005) A basic Finnish climate data set 1961-2000 - description and illustrations. FMI Rep $5: 27$

Venier LA, Hopkin AA, McKenney DW, Wang YA (1998) A spatial, climate-determined risk rating for Scleroderris disease of pines in Ontario. Can J For Res 28:1398-1404

Virtanen T, Neuvonen S, Nikula A, Varama M, Niemelä P (1996) Climate change and the risks of Neodiprion sertifer outbreaks on Scots pine. Silva Fenn 30:169-177

Wulff S, Hansson P, Witzell J (2006) The applicability of national forest inventories for estimating forest damage outbreaks experiences from a Gremmeniella outbreak in Sweden. Can For 36:2605-2613 